Journal of Advanced Research in Fluid Mechanics and Thermal Sciences

\title{
Energy Savings in a Multi-Circuit Water-Cooled Packaged Unit Air-Conditioning System
}

\author{
Hayati Abdullah ${ }^{1,}{ }^{*}$, Oleolo Ibrahim ${ }^{1}$, Mohammad Nazri Mohd Jaafar ${ }^{1}$, Mohamad Maziah ${ }^{1}$, Akmal \\ Baharain $^{1}$, Sapiah Sulaiman ${ }^{2}$
}

School of Mechanical Engineering, Faculty of Engineering, Universiti Teknologi Malaysia, 81310 UTM Johor Bahru, Johor, Malaysia

Smart Digital Community Research Alliance Universiti Teknologi Malaysia, 81310 UTM Johor Bahru, Johor, Malaysia

\section{ARTICLE INFO}

\section{Article history:}

Received 21 June 2020

Received in revised form 27 July 2020

Accepted 27 July 2020

Available online 8 October 2020

Keywords:

Multi-Circuit; Water-Cooled Packaged Unit; Energy Savings

\section{ABSTRACT}

Air-conditioning systems accounts for the highest portion of energy consumption in buildings, either commercial or residential. Thus, there is a need for energy savings while ensuring internal thermal comfort. The compressor utilizes about $90 \%$ of the energy being consumed by the air-conditioning system. Common practice in energy savings for air-conditioning systems includes the application of variable frequency drive of the compressor for capacity control. However, literature on capacity control for operational centralized multi-circuit systems are scarce. This paper presents a study on the application of a thermal control system known as the Advanced Thermal Control System or ATCS utilizing variable frequency drive technology on an installed and operational multi-circuit centralized water-cooled packaged unit air-conditioning system at an administration block in Universiti Teknologi Malaysia. The result shows energy savings of up to $33.0 \%$ when compared to the baseline operation of the existing system.

Copyright @ 2020 PENERBIT AKADEMIA BARU - All rights reserved

\section{Introduction}

Energy management is critical to the growing population of the world. As the population keeps growing, energy demand keeps increasing, resulting in higher priority for adequate control of energy consumption [1]. The building sector is among the highest consumer of energy and accounts for a significant percentage of a nation's energy consumption [2]. In the United States, energy consumption in buildings makes up for $41 \%$ of the total energy consumption in 2010 [3]. The electrical energy being consumed was the major factor that led to the $58 \%$ growth in net domestic generation between 1985 and 2006 [4]. Energy consumption in the building sector has also been studied by Bakar et al., [5] and Figure 1 shows the percentage of energy consumption for the building sector in several countries. The figure shows a $23 \%$ consumption rate for Spain [3], $25 \%$ for

\footnotetext{
* Corresponding author.

E-mail address: hayatiabdullah@utm.my
}

https://doi.org/arfmts.76.1.3953 
Japan [6], 28\% for China [7], 39\% for United Kingdom [3], 42\% for Brazil [9], 47\% for Switzerland [8], and $50 \%$ for Botswana [10].

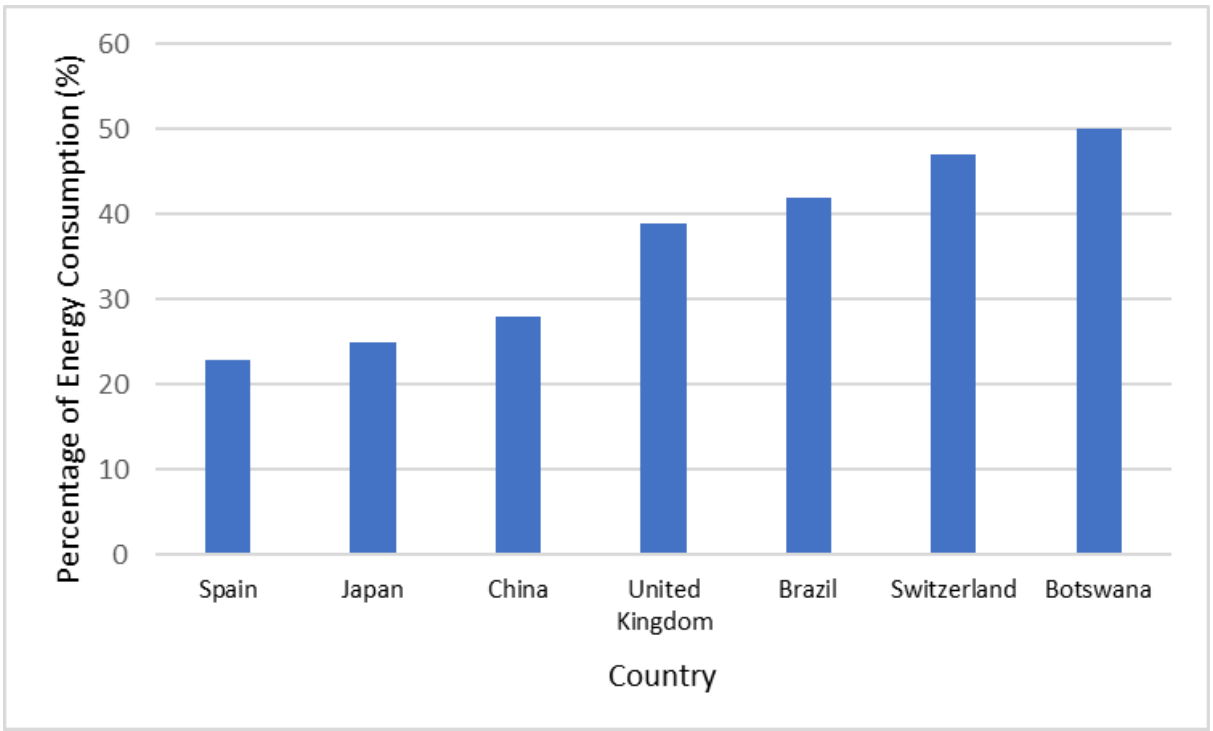

Fig. 1. Percentage of energy consumption for the building sector in several countries [5]

World energy consumption for buildings keeps on growing, accounting for about $40 \%$ of the primary energy consumption and this is forecasted to increase to about 45\% in the year 2025 [5]. HVAC is the largest consumer of energy in the buildings and as a result, the increase use of the airconditioning system will have a significant impact on the total energy consumption [11]. As such, any slight reduction in the energy consumption of the HVAC system will result in a positive impact on the building's energy management program [12].

The main function of the HVAC system is to provide thermal comfort for the occupants of the indoor space. In view of the need for environmental sustainability, it is important to provide thermal comfort with the least energy usage. Population growth, increased thermal comfort requirements and global climate change have contributed to an upward trend in the use of HVAC systems and as such an increase in energy consumption in the building sector. Consequently, most countries concentrate on the building sector as having the greatest energy saving potentials. Studies have shown that a small increase in system operating efficiency can result in significant energy savings [13].

The vapor compression refrigeration cycle is commonly utilized in conventional building airconditioning systems with the compressor being the major consumer of energy [14-15]. Multirefrigerant circuit systems are becoming more common in building air-conditioning systems providing some degree of flexibility in capacity control in matching the building's cooling demand with the system's operating capacity. However, the common practice for centralized airconditioning systems in commercial buildings and offices is such that the compressor is set to operate at maximum speed which could result in over cooling of the conditioned space. This could also lead to indoor thermal discomfort and a waste of energy [16]. Thus, there is a need for capacity control in ensuring energy savings and thermal comfort is achieved. Variable frequency drive of the motor of the compressor is often utilized for capacity control of air-conditioning systems [17]. Variable frequency drive allows the load powered by alternating current induction motors to operate at different range of speeds, in accordance to the control algorithm based on the system feedback [18-19]. 
Studies on capacity control are most often focused on single circuit air-conditioning system and limited to laboratory scale experiments and simulations [20]. Research studies in the open literature on capacity load matching capability that are carried out on large scale multi-circuit airconditioning systems are scarce [21-22]. This work addresses this research gap and is focused on energy savings, temperature control and system performance of a water-cooled multi-circuit airconditioning system, using a control system utilizing variable frequency drive for the compressor.

\section{Plant Description}

The field work was carried out at an office space located at the ground floor of the Block F54 building in Universiti Teknologi Malaysia, Johor Bahru, Johor. The water-cooled packaged unit (WCPU) is installed in the Air Handling Unit (AHU) room of the Block F54 building. The indoor space is an office environment with an average occupancy of 30 people. The WCPU is operated daily between 8:00 am until 4:00 pm from Sunday to Thursday. The air-conditioning system set point temperature was $25^{\circ} \mathrm{C}$. Figure 2 shows the layout of the office space in the Block F54 building.

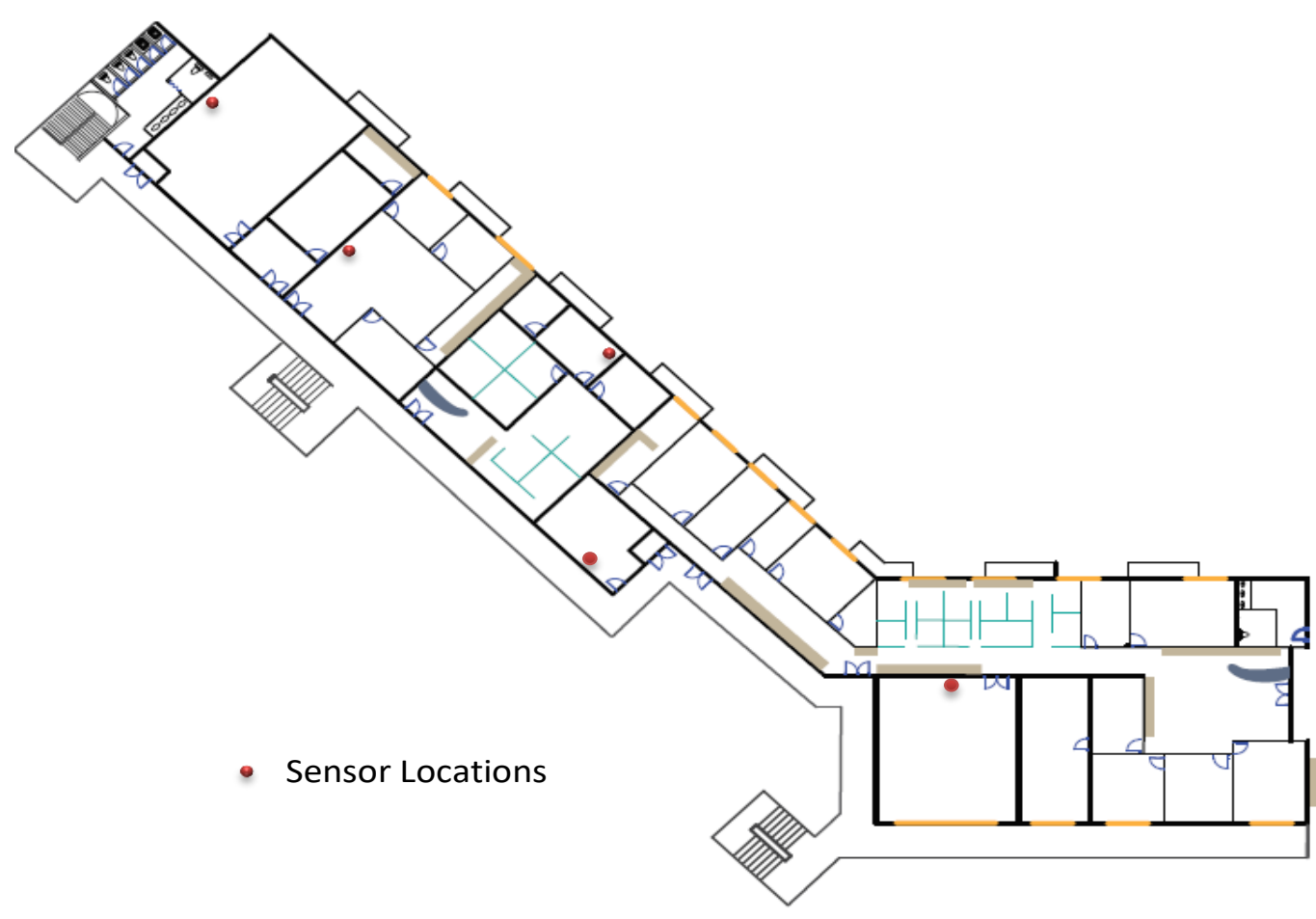

Fig. 2. Layout of the office space in the block F54 building, Universiti Teknologi Malaysia

The water-cooled packaged unit consists of two refrigeration circuits in parallel. Each circuit consists of a direct expansion evaporator coil with expansion valve, water-cooled condenser and a scroll type compressor. The two refrigeration circuits were designed to provide partial capacity in case of failure of any of the compressors. Each refrigeration circuit is a vapor compression cycle where the refrigerant enters the compressor as a vapor and is compressed to the pressure of the condenser. Cooled air is supplied to the indoor space via the blowers and ducting. Figure 3 shows the WCPU at the ground floor of the Block F54 building. The conventional method of control operation for the installed WCPU is the on/off thermostat control. 


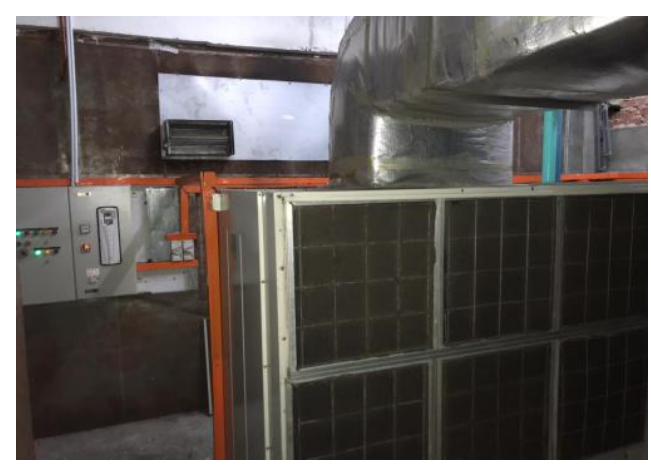

Fig. 3. WCPU at Block F54

\subsection{Data Collection}

Data collection involves logging of parameters including compressor power input, temperatures and humidity at various locations. Two sets of data were collected for two modes of operation. The first set of data were collected during the operation of the WCPU using the on/off thermostat control. The second set of data were collected during the operation of the WCPU using a control system utilizing variable frequency drive for the compressor which is known as the Advanced Thermal Control System or ATCS [23]. Table 1 lists the measured parameters and the measuring instruments. Figure 4 shows the installation of the measuring equipment.

Table 1

Parameters measured and corresponding measuring instruments

\begin{tabular}{|c|c|c|c|c|}
\hline No & Parameter to be measured & Measuring Instrument & Type/Model & Accuracy \\
\hline 1 & $\begin{array}{l}\text { Power input to compressor } \\
1(\mathrm{kw})\end{array}$ & Clamp-on Power Analyzer & Yokogawa IM CW240E & $0.5 \%$ of full scale \\
\hline 2 & $\begin{array}{l}\text { Power input to compressor } \\
2(k w)\end{array}$ & Clamp-on Power Analyzer & Yokogawa IM CW240E & $0.5 \%$ of full scale \\
\hline 3 & Temperature of Supply Air & $\begin{array}{l}\text { EasyLog wifi Temperature } \\
\text { Data Logger }\end{array}$ & $\begin{array}{l}\text { Lascar electronic EL- } \\
\text { WIFI-TH }\end{array}$ & $\pm 0.3^{\circ} \mathrm{C} / \pm 0.6^{\circ} \mathrm{F}$ \\
\hline 4 & Temperature of Mixed Air & $\begin{array}{l}\text { EasyLog wifi Temperature } \\
\text { Data Logger }\end{array}$ & $\begin{array}{l}\text { Lascar electronic EL- } \\
\text { WIFI-TH }\end{array}$ & $\pm 0.3^{\circ} \mathrm{C} / \pm 0.6^{\circ} \mathrm{F}$ \\
\hline 5 & Temperature of Return Air & $\begin{array}{l}\text { EasyLog wifi Temperature } \\
\text { Data Logger }\end{array}$ & $\begin{array}{l}\text { Lascar electronic EL- } \\
\text { WIFI-TH }\end{array}$ & $\pm 0.3^{\circ} \mathrm{C} / \pm 0.6^{\circ} \mathrm{F}$ \\
\hline 5 & $\begin{array}{l}\text { Indoor Temperature (5 } \\
\text { locations) }\end{array}$ & $\begin{array}{l}\text { EasyLog wifi Temperature } \\
\text { Data Logger }\end{array}$ & $\begin{array}{l}\text { Lascar electronic EL- } \\
\text { WIFI-TH }\end{array}$ & $\pm 0.3^{\circ} \mathrm{C} / \pm 0.6^{\circ} \mathrm{F}$ \\
\hline 6 & Outdoor Temperature & $\begin{array}{l}\text { EasyLog wifi Temperature } \\
\text { Data Logger }\end{array}$ & $\begin{array}{l}\text { Lascar electronic EL- } \\
\text { WIFI-TH }\end{array}$ & $\pm 0.3^{\circ} \mathrm{C} / \pm 0.6^{\circ} \mathrm{F}$ \\
\hline 7 & $\begin{array}{l}\text { Supply Air Volumetric flow } \\
\text { rate }\end{array}$ & Air flow meter & $\begin{array}{l}\text { Air velocity transducer } \\
8455 \text { series }\end{array}$ & $\begin{array}{l} \pm 2.0 \% \text { of reading } \\
\pm 0.5 \% \text { of full scale of } \\
\text { selected range }\end{array}$ \\
\hline 8 & $\begin{array}{l}\text { Relative Humidity of } \\
\text { Supply Air }\end{array}$ & $\begin{array}{l}\text { EasyLog wifi Humidity Data } \\
\text { Logger }\end{array}$ & $\begin{array}{l}\text { Lascar electronic EL- } \\
\text { GFX-2 }\end{array}$ & $\pm 2 \% \mathrm{RH}$ \\
\hline 9 & $\begin{array}{l}\text { Relative Humidity of Mix } \\
\text { Air }\end{array}$ & $\begin{array}{l}\text { EasyLog wifi Humidity Data } \\
\text { Logger }\end{array}$ & $\begin{array}{l}\text { Lascar electronic EL- } \\
\text { GFX-2 }\end{array}$ & $\pm 2 \% \mathrm{RH}$ \\
\hline 10 & $\begin{array}{l}\text { Relative Humidity of } \\
\text { Return Air }\end{array}$ & $\begin{array}{l}\text { EasyLog wifi Humidity Data } \\
\text { Logger }\end{array}$ & $\begin{array}{l}\text { Lascar electronic EL- } \\
\text { GFX-2 }\end{array}$ & $\pm 2 \% \mathrm{RH}$ \\
\hline 11 & $\begin{array}{l}\text { Relative Humidity of } \\
\text { indoor Air ( } 5 \text { locations) }\end{array}$ & $\begin{array}{l}\text { EasyLog wifi Humidity Data } \\
\text { Logger }\end{array}$ & $\begin{array}{l}\text { Lascar electronic EL- } \\
\text { GFX-2 }\end{array}$ & $\pm 2 \% \mathrm{RH}$ \\
\hline 12 & $\begin{array}{l}\text { Relative Humidity of } \\
\text { outdoor Air }\end{array}$ & $\begin{array}{l}\text { EasyLog wifi Humidity Data } \\
\text { Logger }\end{array}$ & $\begin{array}{l}\text { Lascar electronic EL- } \\
\text { GFX-2 }\end{array}$ & $\pm 2 \% \mathrm{RH}$ \\
\hline
\end{tabular}


The photographs in Figure 4 also shows the measuring instruments used in the data collection of key parameters.

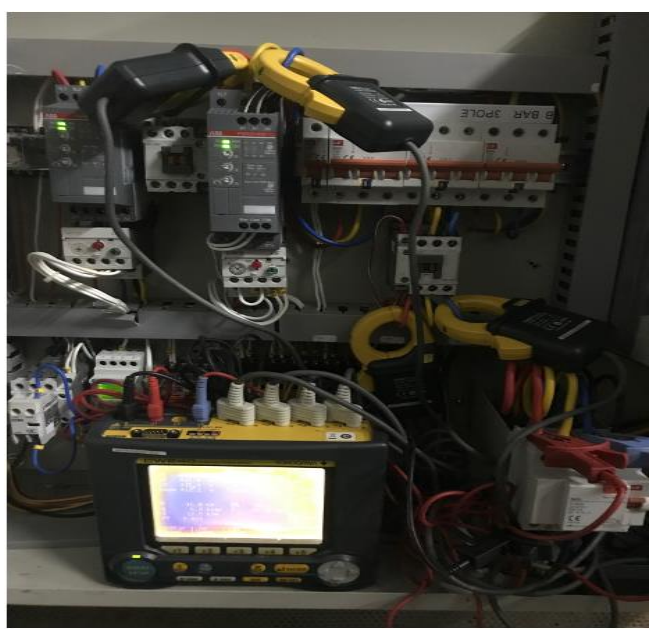

(a) Power analyzer

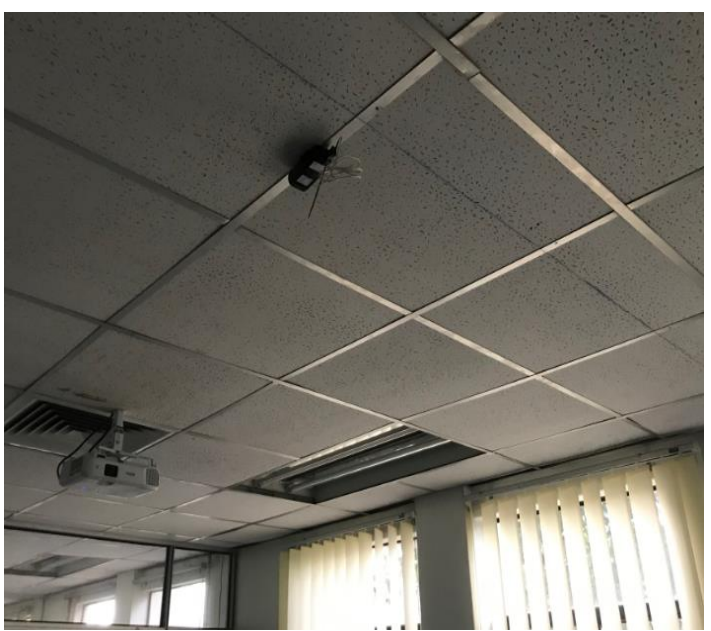

(b) Temperature and humidity data logger

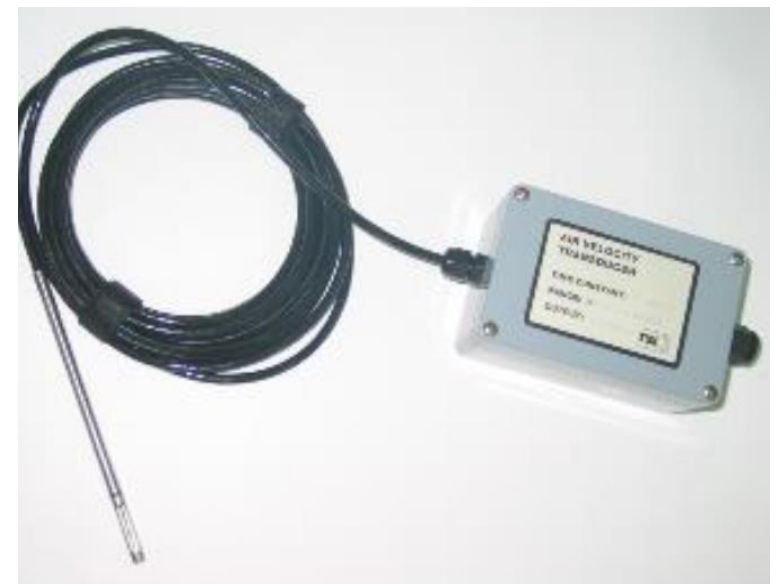

(c) Air flow meter

Fig. 4. The measuring instruments used in the data collection of key parameters

\subsection{Description of Advanced Thermal Control System (ATCS)}

The water-cooled packaged unit (WCPU) conventional control method is the on/off cycling of the compressor. This mode of control has resulted in overcooling of the indoor space. This has given rise to the necessity of developing an enhanced digital control strategy which takes advantage of the combined operation of a variable speed compressor and a constant speed compressor of the WCPU. The strategy is referred to as the Advanced Thermal Control System (ATCS) [23]. The ATCS comprises of a digital temperature controller, an inverter and a soft starter. The digital temperature controller has two outputs. A built-in PID controller is connected to an inverter which converts DC power to AC power and produces the required power needed at a particular point in time according to the feedback from the indoor space by a temperature sensor. This in turn controls and varies the frequency of the motor of compressor 1 , thus making it a variable speed compressor. The other output is connected to the soft starter which replaces the auto-transformer for the on/off control of the constant speed compressor 2 . The soft starter is used in the system to limit the surge of current and torque of the compressor motor, resulting in a safer, smoother and gradual start-up. This protects the motor from possible damage, at the same time 
extend its life span and also reduces the start-up electrical energy consumption of the system. Figure 5 shows a schematic of the ATCS.

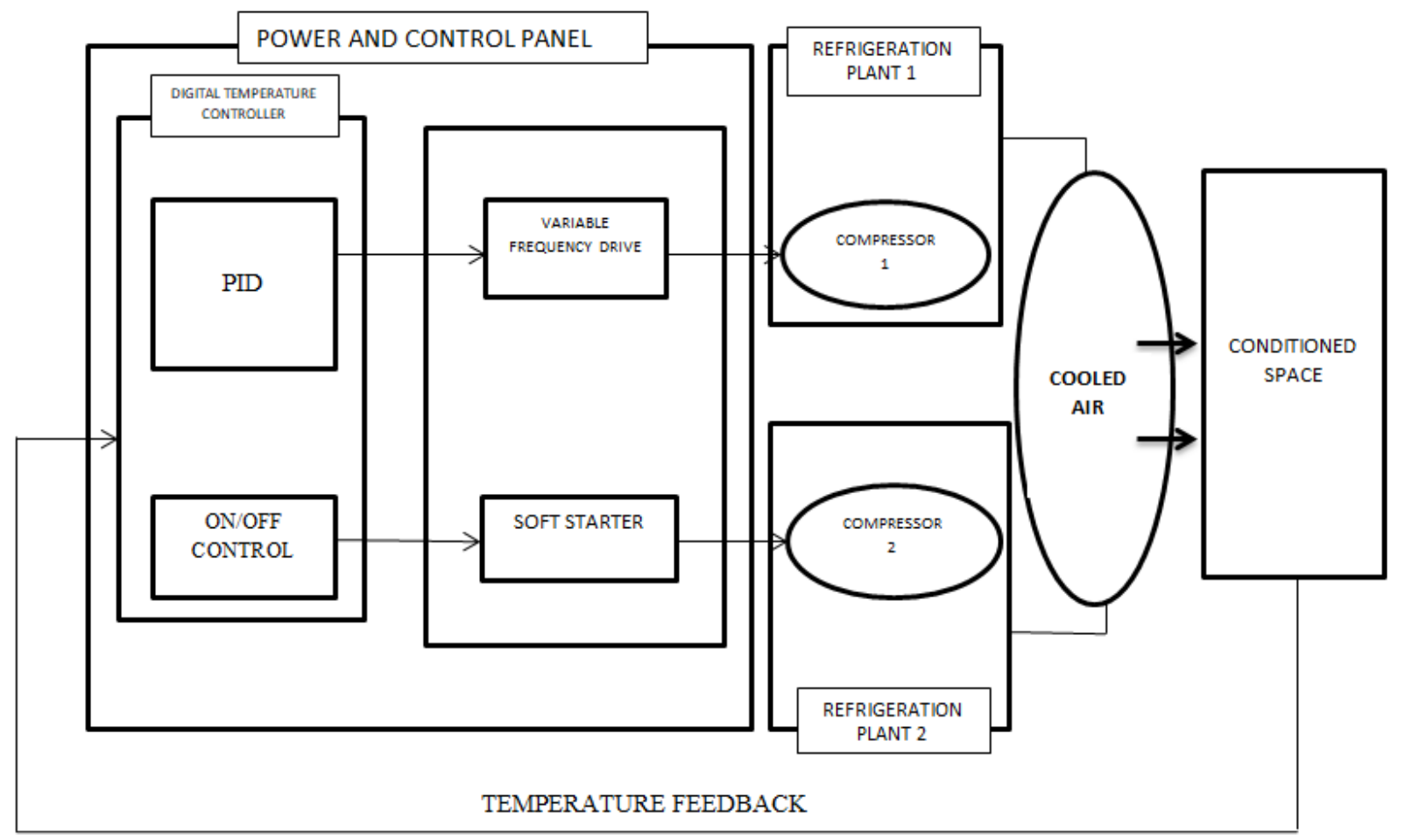

Fig. 5. Advanced Thermal Control System (ATCS)

The set-point of an air conditioning system is not always maintained for the conventional on/off control as the output frequently changes. This can be avoided by the introduction of a temperature band [24]. In this study a temperature band of $0.5^{\circ} \mathrm{C}$ was used and the set point TsP was $25^{\circ} \mathrm{C}$. The temperature of the indoor space, $\mathrm{T}_{\mathrm{s}}$ is the feedback to the control system. The algorithm below explains the operation of the ATCS, with regards to the compressor 1, compressor 2, set-point temperature, temperature band, and indoor temperature. Figure 6 shows the control panel for the conventional on/off control and ATCS.

if $T_{\text {IS }} \leq\left(T_{S P}+0.2\right)$

Compressor 1: Variable speed

Compressor 2: Off

else if $T_{1 S} \geq\left(T_{S P}+0.7\right)$

Compressor 1: Maximum speed

Compressor 2: On

else

Compressor 1: Variable speed

Compressor 2: On

End 


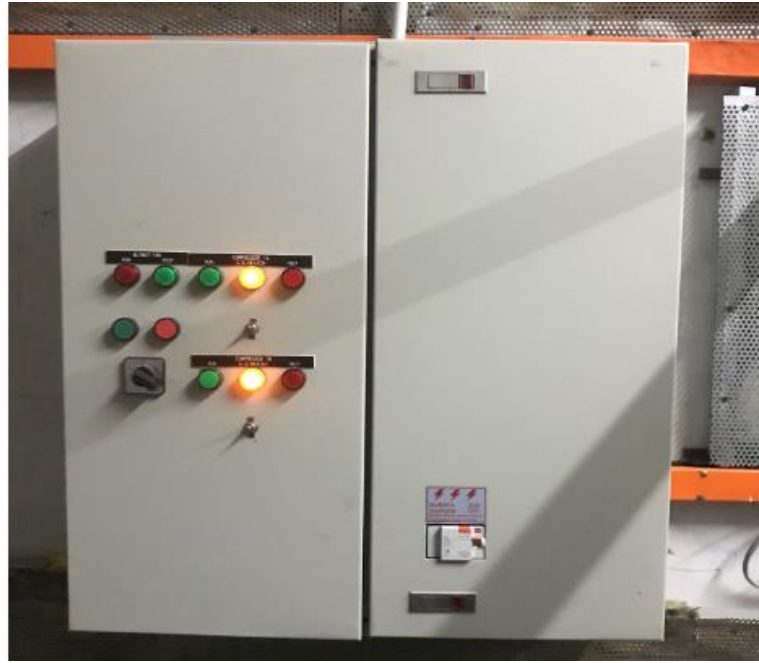

(a) Panel with on/off

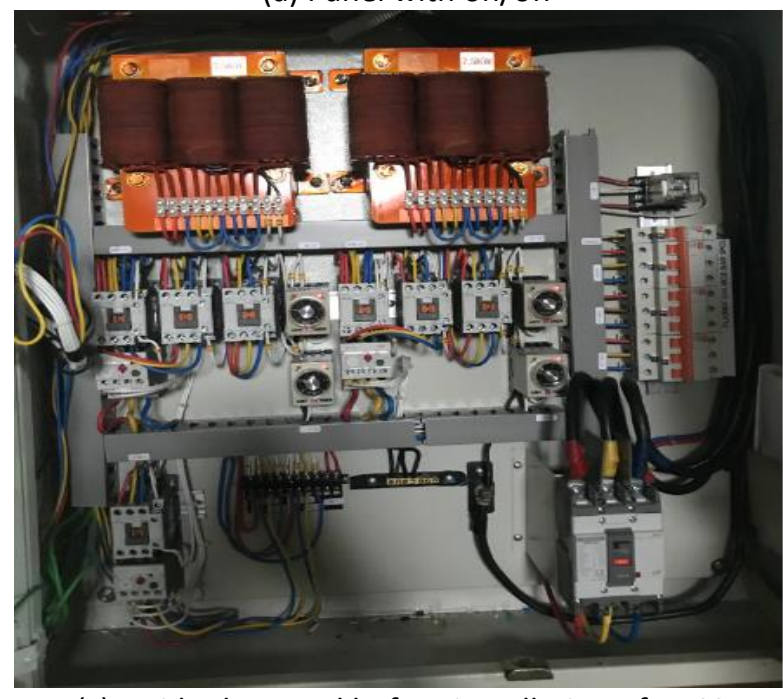

(c) Inside the panel before installation of ATCS

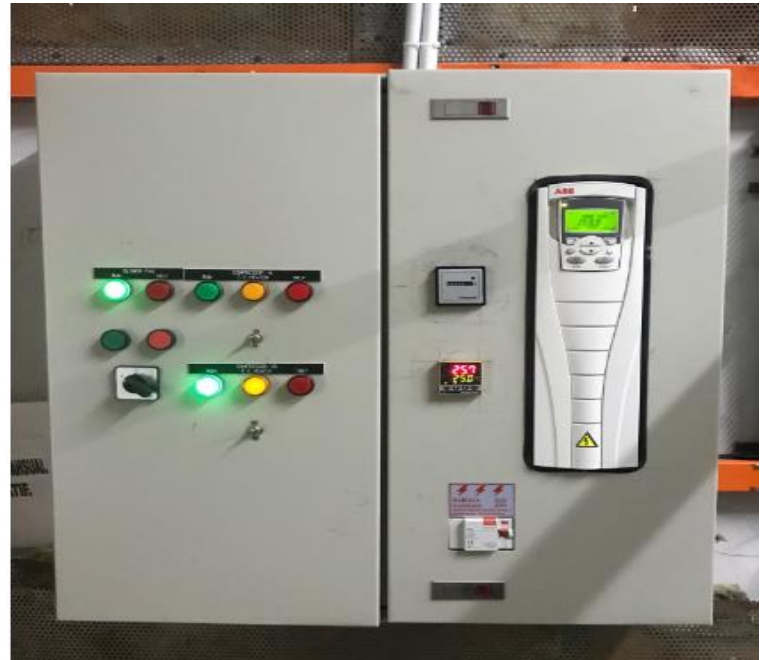

(b) Panel with ATCS

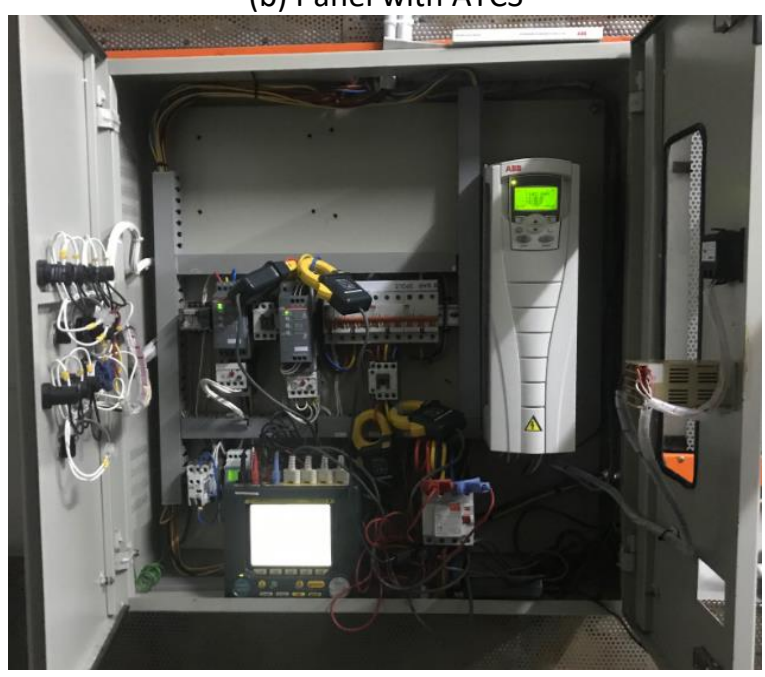

(d) Inside the panel after installation of ATCS with inverter and soft starter

Fig. 6. The control panel for the conventional on/off control and ATCS

\section{Results}

This section presents the analysis of the performance of the WCPU with the installation of the ATCS. Energy consumption, which is the measure of the total power consumption by the two compressors of the WCPU for both modes of on/off and ATCS operations were monitored and recorded for a period of one week ( 5 working days) each. The working days in Johor, Malaysia are from Sunday to Thursday. Data for energy consumption for the on/off operation were monitored and recorded from $2^{\text {nd }}$ April 2019 until $8^{\text {th }}$ April 2019. Data for energy consumption for the ATCS operation were monitored from $8^{\text {th }}$ March to $12^{\text {th }}$ March 2020 . The performance of an airconditioning system is evaluated by the Coefficient of Performance or COP of the system. The Malaysian Standard MS1525:2014 defines COP as the ratio of the rate of net heat removal to the rate of total energy input, expressed in consistent units and under designed rating conditions. 


\subsection{Coefficient of Performance}

The Coefficient of Performance of the WCPU is given as

$\mathrm{COP}=\frac{\text { Cooling Load, } \mathrm{Q}_{\mathrm{cc}}}{\text { Compressor Work Input, } \mathrm{W}_{\mathrm{comp}}}$

For this study, the rate of net heat removal is taken as the evaporator cooling load and the rate of total energy input is taken as the total compressor power input. The components of the cooling load include the sensible and latent heat loads. Based on the principle of heat balance for the air entering the evaporator, the cooling load is given as

Total enthalpy of air entering = Total enthalpy of air leaving + cooling load + heat energy of condensate. The heat energy of condensate is small and assumed to be negligible. The cooling load, $Q_{c c}$ can be calculated below

$\mathrm{Q}_{\mathrm{cc}}=$ Sensible Heat + Latent Heat $=\mathrm{Q}_{\mathrm{s}}+\mathrm{Q}_{\mathrm{l}}$

\subsubsection{Sensible heat $Q_{S}$}

Sensible heat gain based on the fundamental principle is given as

$\mathrm{Q}_{\mathrm{s}}=$ (mass flow rate of supply air) $\mathrm{x}$ (specific heat capacity) $\mathrm{x}$ (temperature change)

$\mathrm{Q}_{\mathrm{s}}=\dot{\mathrm{m}} \times \mathrm{c} \times \Delta \mathrm{T}$

where

$\dot{\mathrm{m}}=$ mass flow rate of supply air

$\Delta T=$ (Temperature of mixed air - Temperature of supply air)

$\mathrm{c}=$ specific heat capacity of dry air and water vapour

In this case, it is necessary to consider the volumetric flow rate, as it is more relevant when considering air distribution fittings, duct system and air handling unit.

Since $\rho=\frac{\dot{m}}{\dot{V}}$

$\mathrm{Q}_{\mathrm{s}}=\rho \times \dot{\mathrm{V}} \times \mathrm{c} \times \Delta \mathrm{T}$

$\dot{V}=$ Volumetric air flow rate, $\mathrm{m}^{3} / \mathrm{s}$

$\rho=$ the density of air, $\mathrm{kg} / \mathrm{m}^{3}$

The density at standard air values as specified in ASHRAE handbook 2005 [25] is given as $=1.20$ $\mathrm{kg} / \mathrm{m}^{3}$. The air supplied to a conditioned room in order to remove the sensible heat gains occurring in them is a mixture of dry air and water vapor. Therefore considering $1 \mathrm{~kg}$ of dry air with an associated moisture content of $\mathrm{w} \mathrm{kg}$ of water vapor, the specific heat capacity of the humid air is given as 


$$
c=1.005+1.82 w
$$

where 1.005 and 1.82 are the specific heats of dry air and water vapor respectively and $\mathrm{w}=$ humidity ratio, $\mathrm{kg}$ (water)/kg (dry air). The approximate condition found in many air-conditioning systems show that $\mathrm{w}=0.01$.

Therefore $\mathrm{c}=1.023 \mathrm{~kJ} / \mathrm{kg}$. From Eq. (4), sensible heat is given as

$\mathrm{Q}_{\mathrm{s}}=1.23 \dot{\mathrm{V}} \Delta \mathrm{T}$

\subsubsection{Latent heat $Q_{l}$}

Latent heat gain $=$ (mass flow rate of supply air) $\times$ (change in humidity ratio) $\times$ (latent heat of evaporation)

$\mathrm{Q}_{\mathrm{l}}=\dot{\mathrm{m}} \times \Delta \mathrm{w} \times \mathrm{h}$

$\mathrm{Q}_{\mathrm{l}}=\rho \times \dot{\mathrm{V}} \times \Delta \mathrm{w} \times \mathrm{h}$

where

$\Delta \mathrm{w}=\mathrm{W}_{\text {mixed air }}-\mathrm{W}_{\text {supply air }}$

$\dot{V}=$ Volumetric air flow rate, $\mathrm{m}^{3} / \mathrm{s}$

$\rho=$ the density of air, $\mathrm{kg} / \mathrm{m}^{3}$

$\mathrm{h}=$ latent heat of evaporation in $\mathrm{kJ}$ per kg moisture

The density at standard air values as specified in ASHRAE handbook 2005 [25] is given as $=1.20$ $\mathrm{kg} / \mathrm{m}^{3}$. The approximate heat content at $50 \% \mathrm{RH}$ vapour is $2500 \mathrm{KJ} / \mathrm{kg}$. Therefore,

$\mathrm{Q}_{\mathrm{l}}=1.20 \times 2500 \dot{\mathrm{V}} \Delta \mathrm{w}$

The coefficient of performance (COP) at an hourly basis for each day, was calculated based on the above equations for both modes of on/off and ATCS operations. Figure 7 below shows the COP results for both modes of operation on selected days for comparison purposes. The MS 1525:2014 specifies the minimum COP for a water-cooled air-conditioner ( $\geq 35 \mathrm{kWr}$ ) to be in the range between 3.8 (non-inverter type) to 4.4 (inverter type). The red lines on the graphs show the range as specified in the MS 1525: 2014. It can be observed that the COP for the on/off operation of the WCPU is mostly at or below the recommended COP range whilst the COP of the ATCS operation is well within and above the recommended COP range. It can also be observed for the ATCS operation in Figure 7(b), as the load decreases in the afternoon (after $2.00 \mathrm{pm}$ ), the ATCS is able to react to the change in load, consuming less power and resulting in a higher COP.

\subsection{Energy Consumption}

The power consumption in this study is the measure of the total power consumption by the two compressors and it is measured in watt. The instrument used for measuring is the Clamp-on Power analyser. The data for power consumption for both the on/off control and ATCS mode of operations were taken at per minute basis for each day. The energy consumption is then computed for each 
working day. The total energy consumption for 5 working days for the on/off control operation were determined for the period of study from $2^{\text {nd }}$ April 2019 until $8^{\text {th }}$ April 2019. The total energy consumption for 5 working days for the ATCS operation were determined for the period of study from $8^{\text {th }}$ March until $12^{\text {th }}$ March 2020.

One of the important parameters that was monitored is the indoor temperature. An important aspect of an air-conditioning system is the ability to maintain the set point indoor temperature. Figure 8 below shows the indoor temperature profiles for two days of the study period. It can be observed that the ATCS was able to maintain a constant indoor temperature as compared to the on/off control which shows substantial variation from the set point temperature of $25^{\circ} \mathrm{C}$.

\section{COP On/Off (Tuesday 02/04/2019)}

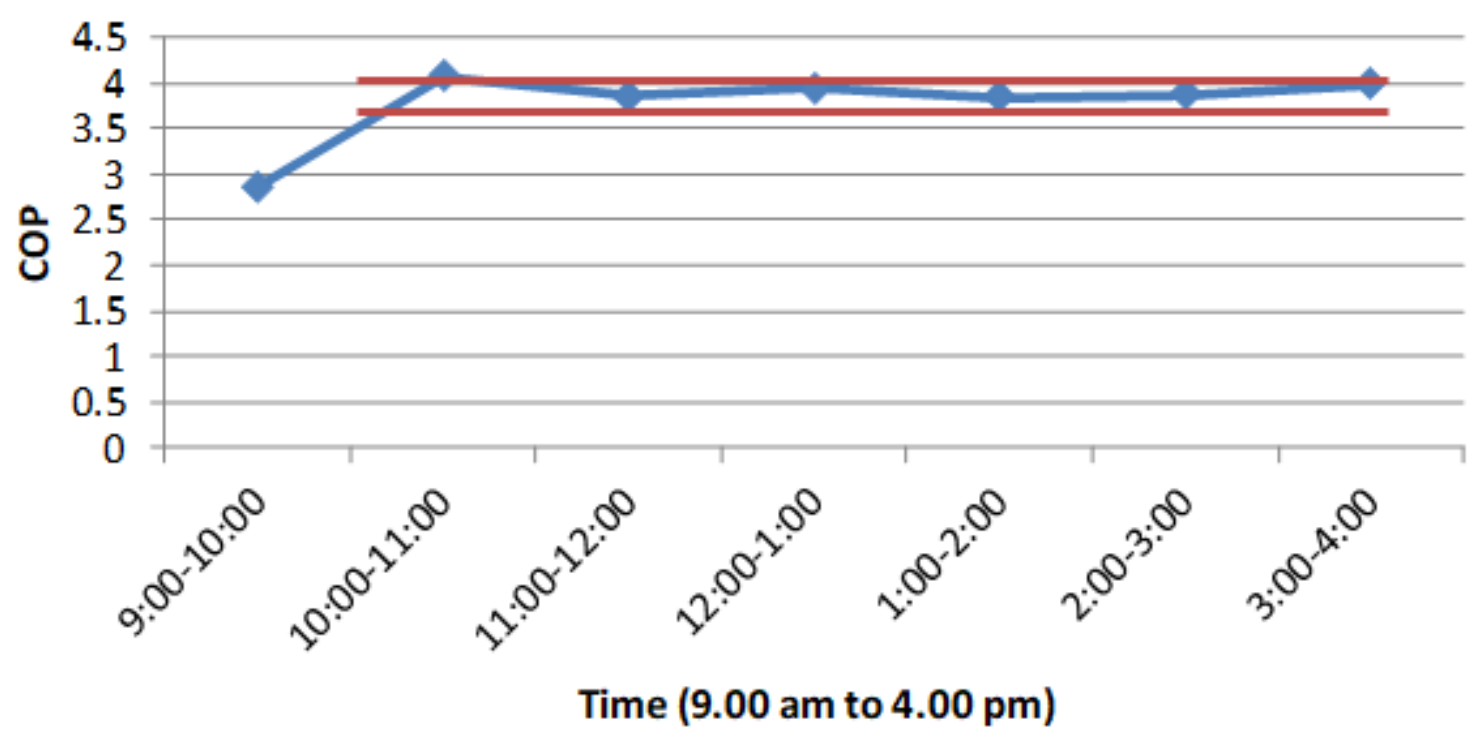

(a) COP for on/off operation

\section{COP ATCS (Tuesday 10/03/2020)}
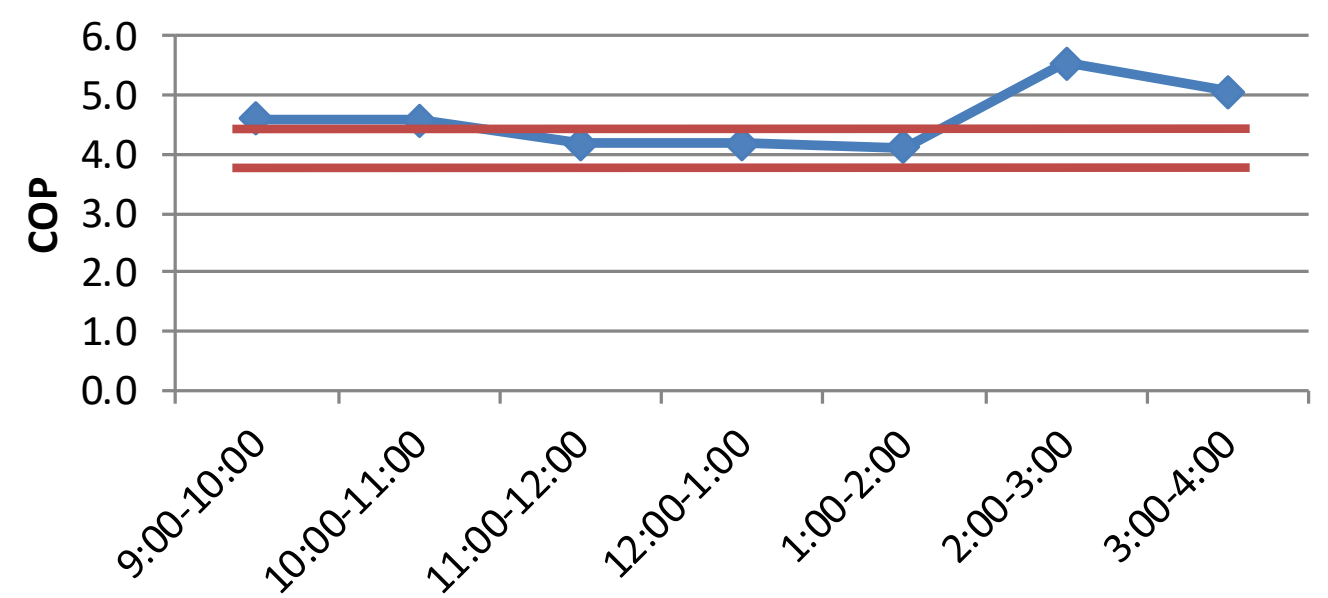

Time $(9.00$ am to $4.00 \mathrm{pm})$

(b) COP for ATCS operation

Fig. 7. The COP results for both modes of operation on selected days for comparison purposes 


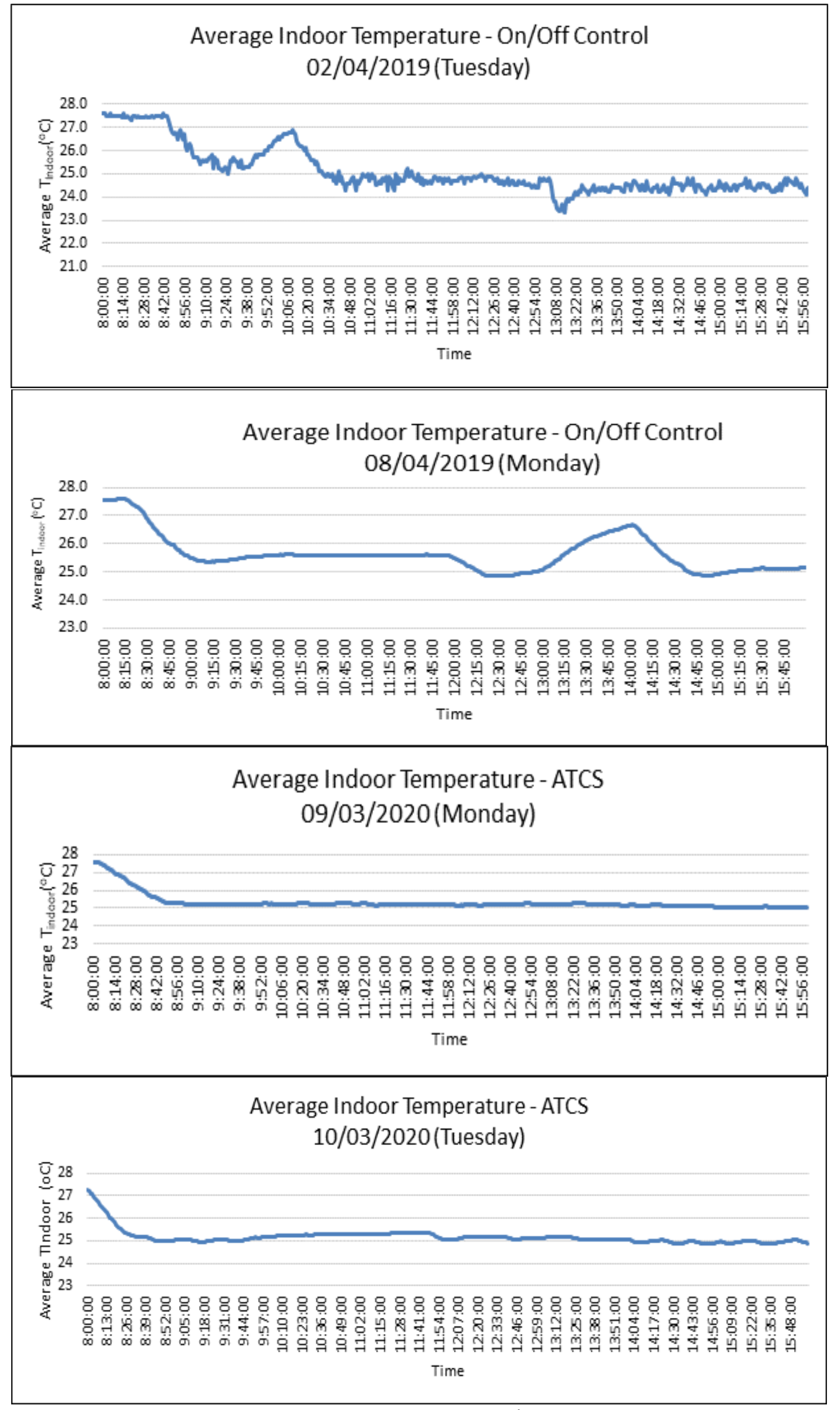

Fig. 8. Indoor temperature profile for On/Off control and ATCS 
Figure 9 shows the total daily energy consumption for two days of the study period. It can be observed that the installation of the ATCS could significantly reduce the load profile of the WCPU resulting in substantial reduction in the energy consumption. The use of the combination of a variable speed compressor and a constant speed compressor in the ATCS for the two-circuit refrigeration plant of the WCPU can be seen to effectively reduce the energy consumption whilst maintaining the targeted indoor temperature.

Table 2 shows the comparison of the energy consumption between the On/Off control and the ATCS for the said period of study. The total energy consumption for the WCPU utilising the On/Off control was $465.7 \mathrm{kWh}$ for the period of study from $2^{\text {nd }}$ April 2019 until $8^{\text {th }}$ April 2019. The total energy consumption for the WCPU utilising the ATCS was $312.2 \mathrm{kWh}$ for the period of study from $2^{\text {nd }}$ April 2019 until $8^{\text {th }}$ April 2019. It can be seen that utilising ATCS to match the load with the system's capacity could result in an energy savings of $33 \%$.
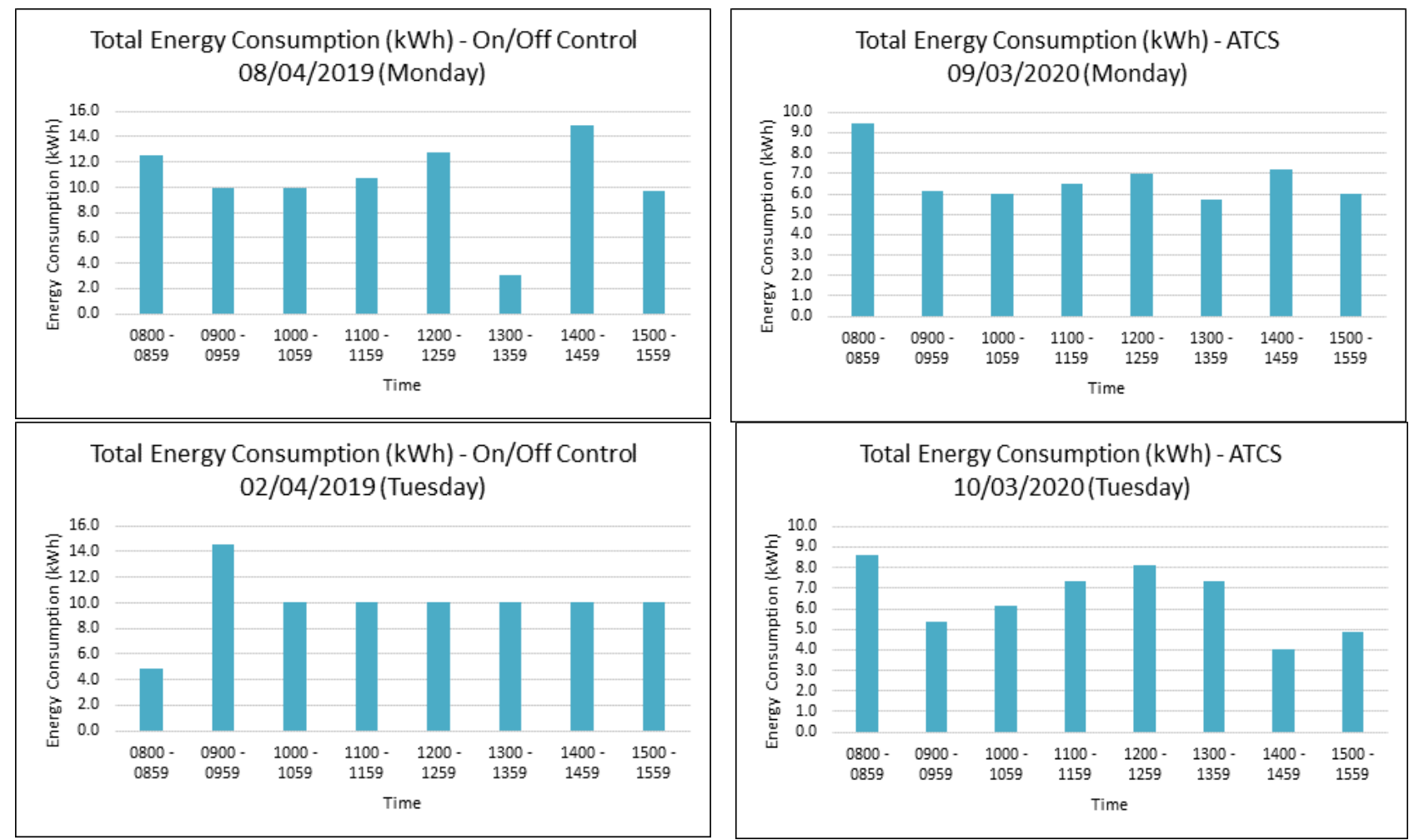

Fig. 9. Daily energy consumption for On/Off control and ATCS operations

\section{Table 2}

Comparison of Energy Consumption between On/Off Control and ATCS

\begin{tabular}{lllc}
\hline $\begin{array}{l}\text { On/Off Control } \\
\text { Date }\end{array}$ & $\begin{array}{l}\text { Energy Consumption } \\
(\mathrm{kWh})\end{array}$ & $\begin{array}{l}\text { ATCS Operation } \\
\text { Date }\end{array}$ & $\begin{array}{l}\text { Energy } \\
\text { Consumption(kWh) }\end{array}$ \\
\hline 02 April 2019 (Tuesday) & 79.8 & 10 March 2020 (Tuesday) & 51.7 \\
03 April 2019 (Wednesday) & 113.1 & 11 March 2020 (Wednesday) & 65.7 \\
04 April 2019 (Thursday) & 101.4 & 12 March 2020 (Thursday) & 70.4 \\
07 April 2019 (Sunday) & 87.9 & 08 March 2020 (Sunday) & 70.3 \\
08 April 2019 (Monday) & 83.5 & 09 March 2020 (Monday) & 54.1 \\
Total & 465.7 kWh & & $312.2 \mathrm{kWh}$ \\
Percent Difference & & $33.0 \%$ & \\
\hline
\end{tabular}


The outdoor condition for the two periods of the on/off and ATCS operations were taken into consideration as shown in Figure 10 below. The outdoor condition for both operations shows a slight difference. Although, the ATCS operation period shows a slightly higher outdoor temperature profile, the WCPU operation with ATCS consumed less energy when compared to the on/off operation of the WCPU.
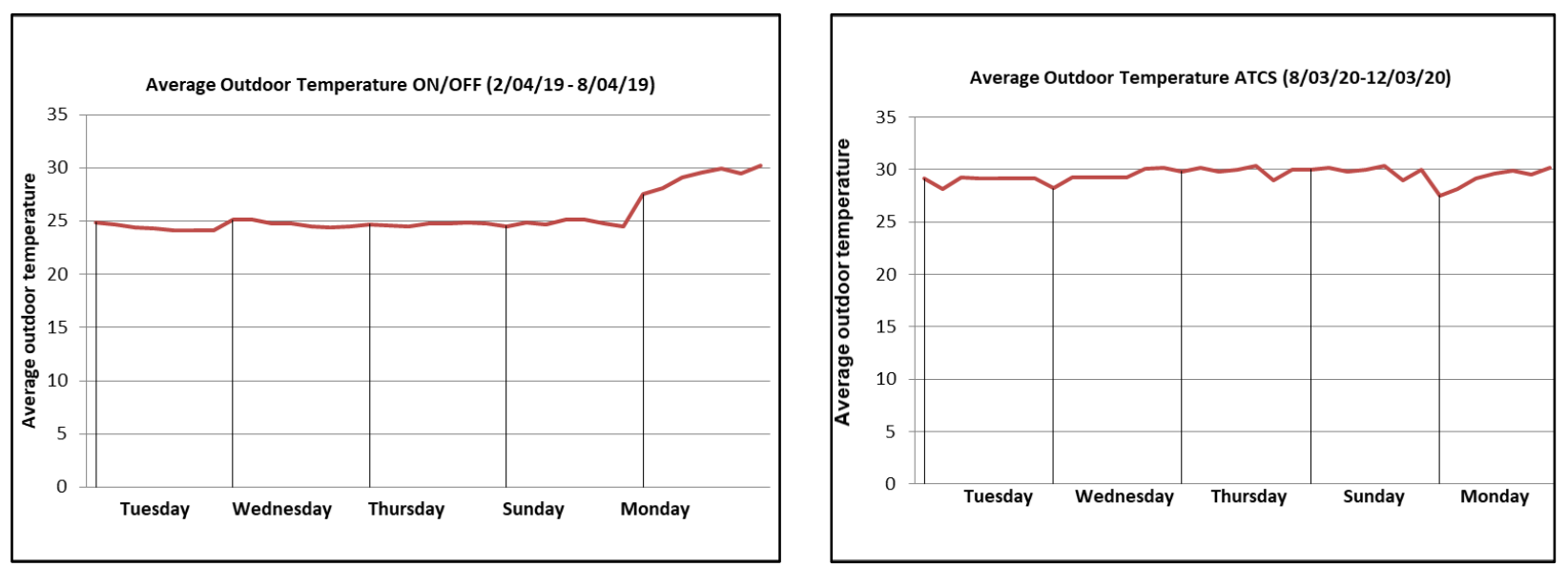

Fig. 10. Average outdoor temperature profile for On/Off control and ATCS

\section{Conclusions}

The ATCS was used to replace the on/off control in an actual two-circuit water cooled packaged unit of a building air-conditioning system. The results show significant improvement in the COP and energy consumption. A substantial reduction of $33.0 \%$ in energy consumption was able to be achieved in this study. The energy savings achieved in this study are comparable to those published in the literature for variable speed operation of compressors in small-scale air-conditioning systems. Thus, substantial energy savings as that achieved for the small-scale applications could be realized with actual medium scale air-conditioning units through the use of the ATCS. The improvement in the coefficient of performance of the actual system was also significant when compared to the conventional On/Off control operation and were found to be within the range of recommended values by the MS1525:2014 standard for water-cooled packaged units. Also, the ATCS was able to maintain the set point temperature of $25^{\circ} \mathrm{C}$ as compared to the on/off control method, which shows a high variation from the set point. As the present study is limited to temperature control only, there is great potential for future studies to consider both temperature and humidity control.

\section{Acknowledgement}

This work was supported by the Ministry of Higher Education Malaysia and Universiti Teknologi Malaysia through the Translational Research Grant (UTM-TRG) Vot $4 J 337$.

\section{References}

[1] Zhong, Ziwen, Xiangguo Xu, Xiaobo Zhang, and Zhiyuan Huang. "Simulation based control performance evaluation of a novel fuzzy logic control algorithm for simultaneously controlling indoor air temperature and humidity using a direct expansion (DX) air-conditioning (A/C) system." Procedia Engineering 205 (2017): 1792-1799. https://doi.org/10.1016/j.proeng.2017.10.040

[2] Qureshi, T. Q., and S. A. Tassou. "Variable-speed capacity control in refrigeration systems." Applied Thermal Engineering 16, no. 2 (1996): 103-113. https://doi.org/10.1016/1359-4311(95)00051-E 
[3] Pérez-Lombard, Luis, José Ortiz, and Christine Pout. "A review on buildings energy consumption information." Energy and buildings 40, no. 3 (2008): 394-398.

https://doi.org/10.1016/j.enbuild.2007.03.007

[4] Naimaster IV, E. J., and A. K. Sleiti. "Potential of SOFC CHP systems for energy-efficient commercial buildings." Energy and Buildings 61 (2013): 153-160.

https://doi.org/10.1016/i.enbuild.2012.09.045

[5] Bakar, Nur Najihah Abu, Mohammad Yusri Hassan, Hayati Abdullah, Hasimah Abdul Rahman, Md Pauzi Abdullah, Faridah Hussin, and Masilah Bandi. "Energy efficiency index as an indicator for measuring building energy performance: A review." Renewable and Sustainable Energy Reviews 44 (2015): 1-11. https://doi.org/10.1016/i.rser.2014.12.018

[6] Yoon, Gyu-young, H. Komoda, Hideki Tanaka, and M. Okumiya. "Study on the Energy Conservation Performance of the Air-conditioning System for Building Combined a Double-skin and Earth-to-air Heat Exchanger." In Proceedings of The World Sustainable Building Conference, pp. 27-29. 2005.

[7] Lam, Joseph C., C. L. Tsang, and Liu Yang. "Impacts of lighting density on heating and cooling loads in different climates in China." Energy Conversion and Management 47, no. 13-14 (2006): 1942-1953.

https://doi.org/10.1016/i.enconman.2005.09.008

[8] Zimmermann, M., H-J. Althaus, and A. Haas. "Benchmarks for sustainable construction: A contribution to develop a standard." Energy and Buildings 37, no. 11 (2005): 1147-1157.

https://doi.org/10.1016/i.enbuild.2005.06.017

[9] Delbin, S. I. M. O. N. E., and V. Da Silva. "Energy efficiency simulation of buildings in Brazil: proposal of methodology for insertion in design practice." In Proceedings of the 2005 World Sustainable building Conference, Tokyo, Japan, pp. 27-29. 2005.

[10] Ahmad, Ahmad Sukri, Mohammad Yusri Hassan, Hayati Abdullah, Hasimah Abdul Rahman, Md Shah Majid, and Masilah Bandi. "Energy efficiency measurements in a Malaysian public university." In 2012 IEEE International Conference on Power and Energy (PECon), pp. 582-587. IEEE, 2012. https://doi.org/10.1109/PECon.2012.6450281

[11] Xi-Wen, L., and D. Tie-Feng. "Design for fuzzy decoupling control system of temperature and humidity." In International Conference Communications in Computer and Information Science, China, pp. 231-236. 2011. https://doi.org/10.1007/978-3-642-21402-8 38

[12] Xu, Xiangguo. "Enhanced indoor humidity control in a space served by a Direct Expansion (DX) air conditioning (A/C) system." PhD diss., The Hong Kong Polytechnic University, 2010.

[13] Afram, Abdul, and Farrokh Janabi-Sharifi. "Review of modeling methods for HVAC systems." Applied Thermal Engineering 67, no. 1-2 (2014): 507-519. https://doi.org/10.1016/i.applthermaleng.2014.03.055

[14] Deng, Shiming. "The application of feedforward control in a direct expansion (DX) air conditioning plant." Building and environment 37, no. 1 (2002): 35-40. https://doi.org/10.1016/S0360-1323(00)00090-1

[15] Affandi, Marwan. "Energy Saving in an Air-Conditioning System Using an Inverter and a Temperature-Speed Controller." PhD diss., Universiti Teknologi Malaysia, 2004.

[16] Jingyun, Liu, and Li Ping. "Temperature and humidity control with a model predictive control method in the airconditioning system." In 2017 International Conference on Advanced Mechatronic Systems (ICAMechS), pp. 408412. IEEE, 2017. https://doi.org/10.1109/ICAMechS.2017.8316508

[17] Qi, Qi, Shiming Deng, Xiangguo Xu, and M. Y. Chan. "Improving degree of superheat control in a direct expansion (DX) air conditioning (A/C) system." International journal of refrigeration 33, no. 1 (2010): 125-134. https://doi.org/10.1016/j.ijrefrig.2009.09.005

[18] Zhou, Xinmin, Wei Chen, Qingyong Zhang, and Tao Zeng. "Central Air-conditioning Control System Based on Fuzzy PID Controller." In Proceedings of the 2017 International Conference on Management Engineering, Software Engineering and Service Sciences, pp. 326-329. 2017.

https://doi.org/10.1145/3034950.3034969

[19] Zhang, G. H. "System for Air Conditioning Based on Fuzzy Control." South China University of Technology (2012).

[20] Synnøve Jönsson, Ida. "System identification for control of temperature and humidity in buildings." (2015).

[21] Ko, Young-Sun, and Sang Tae No. "A study on comparison of building energy simulation and measurement results for a city hall." Journal of Building Construction and Planning Research 3, no. 01 (2015): 1. https://doi.org/10.4236/jbcpr.2015.31001

[22] Lü, Xiaoshu, Tao Lu, Charles J. Kibert, and Martti Viljanen. "Modeling and forecasting energy consumption for heterogeneous buildings using a physical-statistical approach." Applied Energy 144 (2015): 261-275. 
https://doi.org/10.1016/i.apenergy.2014.12.019

[23] Md. Nor Musa, Hayati Abdullah and Mohammad Akmal Baharain A. Rahim. PI 2010001770 : A control system and Methods of Maintaining Temperature Thereof. Universiti Teknologi Malaysia (2010).

[24] Behrooz, Farinaz, Norman Mariun, Mohammad Hamiruce Marhaban, Mohd Amran Mohd Radzi, and Abdul Rahman Ramli. "Review of control techniques for HVAC systems-Nonlinearity approaches based on Fuzzy cognitive maps." Energies 11, no. 3 (2018): 495.

https://doi.org/10.3390/en11030495

[25] Handbook-Fundamentals, A. S. H. R. A. E. "SI edition. Atlanta, GA: American Society of Heating, Refrigerating and Air-Conditioning Engineers." (2005). 